\title{
Analytical Assessment and Nutritional Adequacy of School Lunches in Sintra's Public Primary Schools
}

\author{
Telma Nogueira ${ }^{1,2, * \mathbb{D}}$, Raquel J. Ferreira ${ }^{3,4}$, Vitória Dias da Silva ${ }^{1}$, Mariana Liñan Pinto ${ }^{1}$, Carlos Damas ${ }^{4,5}$ \\ and Joana Sousa ${ }^{1,2}$
}

Citation: Nogueira, T.; Ferreira, R.J.; Dias da Silva, V.; Liñan Pinto, M.; Damas, C.; Sousa, J. Analytical Assessment and Nutritional Adequacy of School Lunches in Sintra's Public Primary Schools. Nutrients 2021, 13, 1946. https:// doi.org/10.3390/nu13061946

Academic Editor: Martina Barchitta

Received: 6 May 2021

Accepted: 1 June 2021

Published: 5 June 2021

Publisher's Note: MDPI stays neutral with regard to jurisdictional claims in published maps and institutional affiliations.

Copyright: (c) 2021 by the authors. Licensee MDPI, Basel, Switzerland. This article is an open access article distributed under the terms and conditions of the Creative Commons Attribution (CC BY) license (https:/ / creativecommons.org/licenses/by/ $4.0 /)$.
1 Laboratório de Nutrição, Faculdade de Medicina, Universidade de Lisboa, 1649-028 Lisboa, Portugal; vitoriasilva@medicina.ulisboa.pt (V.D.d.S.); marianapinto@medicina.ulisboa.pt (M.L.P.); joanamsousa@medicina.ulisboa.pt (J.S.)

2 Instituto de Saúde Ambiental, Faculdade de Medicina, Universidade de Lisboa, 1649-028 Lisboa, Portugal

3 Câmara Municipal de Sintra, 2714-501 Sintra, Portugal; raquel.ferreira@cm-sintra.pt

4 Escola Superior de Tecnologia da Saúde de Lisboa, Instituto Politécnico de Lisboa, 1990-096 Lisboa, Portugal; cadamas@estesl.ipl.pt

5 Direção de Qualidade e Ambiente, Indústria e Comércio Alimentar, S.A, 1000-203 Lisboa, Portugal

* Correspondence: telmanogueira@medicina.ulisboa.pt; Tel.: +351-917-651-576

\begin{abstract}
School meals present several cost benefits overtime at the short, medium, and long term for individuals and society. This cross-sectional study aims to analyse the nutritional composition and evaluate the adequacy of school lunches. One hundred and fifty-eight samples were collected and analysed from 10 primary schools in Sintra's municipality, served during one week. On average, energy ( $27.7 \%$ daily energetic requirements) and carbohydrate $(48.1 \%)$ contents did not reach the reference values, and the content of protein $(19.5 \%)$ exceeded the reference value $(p<0.05)$. The mean total fat $(28.8 \%)$ and saturated fatty acids $(5.4 \%)$ content complied with the recommendations. The mean salt $(1.7 \mathrm{~g})$ and dietary fibre $(8.3 \mathrm{~g})$ content exceeded the reference value but did not differ significantly from the recommendations. Addressing school canteens is crucial, not only in a nutritional approach, but also as an opportunity to achieve healthier, sustainable, and accessible food systems, aligned with the Sustainable Development Goals 2030. We highlighted the importance of evaluating evidence-based practices and disseminated practice-based evidence regarding the adequacy of school lunches.
\end{abstract}

Keywords: school; school lunch; food analysis; child nutrition; food system

\section{Introduction}

During childhood, adequate eating habits are crucial for optimal growth, development, health, and wellbeing, as well as for disease prevention [1,2]. Schools are a privileged environment to protect and support adequate nutrition in children and their families and communities $[3,4]$. School meals present several cost benefits overtime at the short, medium, and long term for individuals and society [5]. School meals have a great impact on children's health and wellbeing [6,7]. Providing healthy school meals for all children, regardless of their socioeconomic position, is a recognized strategy for reducing health inequalities [8]. Besides the crucial role of dietary habits in human health, diets are inevitably related to environmental health [9]. Thus, school meals also represent a challenge to environmental sustainability, and they are an opportunity to tackle food waste, protect natural resources and biodiversity, contribute to resilient food systems, and therefore reduce their environmental impact $[10,11]$.

School lunches in Sintra, Portugal, consist of soup (vegetables and/or legumes), a main course (meat, fish, poultry, or a lacto-ovo-vegetarian alternative, served with rice, potatoes, or pasta, and vegetables), dessert (fresh fruit or sweetened dessert once a week), bread, and water as a beverage. 
Children are next-generation consumers, so influencing their eating behaviours could have an impact on the sustainability of the food systems [12,13], as the acquisition of more sustainable habits could continue into adulthood, reducing the amount of waste produced by future generations [12]. Additionally, a healthy school food environment, where the food provided is accessible, enjoyable, safe, and nutritious, enables and encourages the entire school community to make healthy food choices [11].

Dealing with nutrition concerns in childhood requires coherent action in the school setting, so the development of food and nutrition policies are central [3,14]. Several national [15-17] and international $[3,18,19]$ guidelines that aim to regulate and improve the school food environment have been developed. In the past two decades, entities, such as the World Health Organization [20,21], European Commission [22], and Food and Agriculture Organization of the United Nations [23-25], have established action plans to respond to emerging human and environmental health challenges. The signing of the Milan Urban Food Policy Pact reinforces the responsibility of local governments due to their proximity to the community in promoting resilient and sustainable food systems capable of providing adequate nutrition [24]. Governments can take various actions to create a healthy and sustainable school environment, namely setting nutritional standards for school meals, minimizing the exposure to advertisements of foods and beverages high in fat, sugars, and salt [26], counteracting food waste, and setting up school gardens [11].

It has been recognized that the third United Nations Sustainable Development Goal (good health and wellbeing) involves a broad range of social determinants covered by the remaining goals [27]. Sustainable and healthy food systems are directly or indirectly connected to all of the Sustainable Development Goals when all parts of society are seen as interconnected sectors of the biosphere [28]. Therefore, ensuring an adequate school food environment contributes to an integrated response to the United Nations 2030 Agenda for Sustainable Development [24,29].

School meals are crucial to promote healthy and sustainable food behaviours amongst the school community. Nevertheless, data of Portuguese school lunches content and their adequacy are scarce. Thus, this study aims to analyse the nutritional composition and evaluate the adequacy of school lunches served at Sintra's public primary schools' canteens.

\section{Materials and Methods}

\subsection{Study Design, Population, and Sampling}

This analytical observational study was conducted in the municipality of Sintra, Portugal. Sintra's municipality oversees the management of public school meal service in 90 establishments (67 with local confection and 23 with a deferred cook/chill catering system) [30], providing approximately 15,000 school lunches a day. Thus, there are two established lunch menus: a local confection menu and a deferred cook/chill menu (Appendices A and B). The school lunch menus are conceived by registered dietitian/nutritionists considering the nutritional needs of the school population, with regards to the guidelines of the Directorate-General for Education [31]. These guidelines establish the nutritional quality and quantity of the school menu, including the meal composition, portion size, cooking methods, and food sustainable principles [31]. Sintra's municipality has established a cycle of a 15-week school lunch menu for schools with local confection and a cycle of an eight-week school lunch menu for the deferred cook/chill menu. The selection of school canteens for sampling was done by convenience and consisted of school lunch menus from nine primary schools with local confection and from one primary school with a deferred cook/chill catering system. This analysis corresponds to one week of school lunch menus in each school.

\subsection{Data Collection}

In this study, 158 samples were collected and analysed from 10 primary schools from Sintra's municipality, served for one week between 4-8 June 2018. From the 50 school lunches, one soup and one main course was lost during the data collection. In each school, 
samples of soup, the main course, dessert, and bread in the portions that were served to the children were taken. In each school, samples were daily collected and frozen by the canteen manager. Afterwards, laboratory technicians transported the samples to an accredited and independent laboratory. Disposable gloves and masks, precision balance, serving bowls, spoons, disposable paper, and plastic bags were used to collect the samples. It was guaranteed that the sampling area was a properly hygienic environment. The nutritional composition of the samples was obtained by analytic methods conducted by an independent and accredited laboratory considering the techniques presented in Table 1 . The school lunches were analysed for net weight $(\mathrm{g})$, energy $(\mathrm{kcal})$, protein $(\mathrm{g})$, carbohydrates $(\mathrm{g})$, fats (g), saturated fatty acids (SFA) (g), dietary fibre (g), sodium (g), and salt (g) content. The energy value was calculated using the conversion factors established in Regulation (EU) No $1169 / 2011$. The salt content was calculated considering the formula salt $=$ sodium $\times 2.5$. The carbohydrate content was obtained through calculation by difference [32].

Table 1. Analytical methods.

\begin{tabular}{cc}
\hline Parameter & Method \\
\hline Net weight $(\mathrm{g})$ & Gravimetry \\
Energy $(\mathrm{kcal})$ & Calculation based in Regulation (EU) No $1169 / 2011$ \\
Protein $(\mathrm{g})$ & Dumas technique \\
Carbohydrates $(\mathrm{g})$ & Calculation based in Regulation (EU) No $1169 / 2011$ \\
Fats $(\mathrm{g})$ & Pulsed nuclear magnetic resonance \\
SFA $(\mathrm{g})$ & Gas Chromatography with flame-ionization detection \\
Dietary Fibre $(\mathrm{g})$ & Enzymatic/gravimetric \\
Sodium $(\mathrm{g})$ & Flame atomic absorption spectroscopy \\
Salt $(\mathrm{g})$ & Calculation from sodium content based in Regulation (EU) No $1169 / 2011$ \\
\hline
\end{tabular}

SFA: Saturated fatty acids.

\subsection{Assessment of Nutritional Adequacy}

It was considered that lunch should contribute between 30 to $35 \%$ of the daily energy requirements (DER) [33]. The DER of six- to 10-year-old children with different physical activity profiles is $1640 \mathrm{kcal}$ per day, according to the American guidelines [34]. Thus, lunch should contribute between $492 \mathrm{kcal}$ (30\% DER) to $574 \mathrm{kcal}$ (35\% DER) [34]. To calculate protein, carbohydrates, lipids, and SFA requirements, it was considered that lunch should contribute $30 \%$ of the recommended DER, following the methodology used in the national guidelines for school menus [35]. According to the methodology referred to [35], the percentage distribution for one dietary day was considered, according to the World Health Organization (WHO) recommendations [36]: protein 10 to $15 \%$ (12 g to $18 \mathrm{~g}$ ), carbohydrates 55 to $75 \%$ (68 g to $92 \mathrm{~g}$ ), total lipids 15 to $30 \%$ (8 g to $16 \mathrm{~g}$ ), and SFA $<10 \%(<5.5 \mathrm{~g})$. To calculate dietary fibre adequacy, it was considered $30 \%$ of the total daily dietary fibre value recommended [37]. Thus, the minimum content of dietary fibre was $6.89 \mathrm{~g}$ at lunch, considering the daily recommendations of $14 \mathrm{~g}$ per $1000 \mathrm{kcal}[33,34]$. The WHO recommends reducing sodium intake in children to $<2 \mathrm{~g} /$ day of sodium, which corresponds to $<5 \mathrm{~g} /$ day of salt [38]. Therefore, the amount of salt in the school lunches was calculated considering $30 \%$ of the recommended daily salt value, corresponding to $<1.5 \mathrm{~g}$.

\subsection{Statistical Analyses}

Statistical analysis was performed using the Statistical Package for Social Sciences version 24 (IBM Corp, Armonk, NY, USA) and the RStudio version 3.6.3 (RStudio: Integrated Development for R. RStudio, PBC, Boston, MA, USA). The normality distribution of data was verified by the Shapiro-Wilk test. Descriptive statistics were used to characterise the sample expressed by absolute and relative frequencies, for qualitative variables, and mean or median and standard deviations for quantitative variables. Two-sided, one-sample $t$-tests were used to test whether the energetic ( $30 \%$ of DER) and nutritional content means differed from the reference values (the lowest value in the reference interval was chosen, except for total fat, where the highest reference value was used). For the other nutrients 
with a set reference value (dietary fibre, SFA, and salt), the hypotheses tested were that the mean content did not exceed the reference value. The results were considered significant for a $5 \%$ significance level $(p<0.05)$.

\section{Results}

For one week, 50 school lunches from 10 schools (158 samples) equivalent to the portion made available to children were collected and analysed by analytical methods. The final sample was composed of 49 soups, 49 main courses (19 meat dishes, 20 fish dishes, and 10 lacto-ovo-vegetarian dishes), 50 desserts, and 10 breads (one for each school). The weight and nutritional composition of the school lunch samples are presented in Table 2.

Table 2. Weight and nutritional composition of main course, soup, dessert, and bread of school lunches analysed.

\begin{tabular}{|c|c|c|c|c|c|}
\hline & Per Dose & Mean & SD & MIN & MAX \\
\hline \multirow{8}{*}{$\begin{array}{l}\text { MAIN COURSE } \\
\quad(n=49)\end{array}$} & Weight (g) & 233.9 & 56.4 & 132.4 & 359.0 \\
\hline & Energy (kcal) & 277.7 & 285.9 & 131.3 & 504.0 \\
\hline & Carbohydrates (g) & 24.9 & 7.5 & 12.2 & 43.5 \\
\hline & Protein $(\mathrm{g})$ & 17.3 & 7.0 & 5.3 & 40.9 \\
\hline & Total fat (g) & 11.2 & 6.7 & 2.4 & 31.9 \\
\hline & SFA (g) & 1.9 & 0.2 & 0.7 & 4.4 \\
\hline & Dietary Fibre (g) & 4.2 & 3.6 & 0.8 & 18.0 \\
\hline & Salt (g) & 1.0 & 0.4 & 0.4 & 2.2 \\
\hline \multirow{8}{*}{$\begin{array}{l}\text { SOUP } \\
(n=49)\end{array}$} & Weight (g) & 211.0 & 35.9 & 137.9 & 280.3 \\
\hline & Energy (kcal) & 66.0 & 12.5 & 41.4 & 95.1 \\
\hline & Carbohydrates (g) & 8.9 & 2.1 & 4.8 & 14.3 \\
\hline & Protein $(\mathrm{g})$ & 1.8 & 0.7 & 1.0 & 4.5 \\
\hline & Total fat (g) & 2.2 & 0.5 & 1.3 & 3.3 \\
\hline & SFA (g) & 0.5 & 0.1 & 0.3 & 0.7 \\
\hline & Dietary Fibre (g) & 1.9 & 0.7 & 1.0 & 4.8 \\
\hline & Salt $(\mathrm{g})$ & 0.4 & 0.6 & 0.2 & 0.9 \\
\hline \multirow{8}{*}{$\begin{array}{l}\text { DESSERT } \\
(n=50)\end{array}$} & Weight (g) & 93.4 & 14.9 & 52.4 & 132.9 \\
\hline & Energy (kcal) & 57.3 & 20.8 & 24.7 & 109.0 \\
\hline & Carbohydrates (g) & 10.8 & 4.5 & 4.0 & 21.1 \\
\hline & Protein (g) & 1.01 & 0.7 & 0.3 & 3.0 \\
\hline & Total fat (g) & 0.8 & 0.2 & 0.4 & 1.4 \\
\hline & SFA $(g)$ & 0.2 & 0.2 & 0.0 & 0.9 \\
\hline & Dietary Fibre (g) & 1.5 & 0.8 & 0.3 & 3.6 \\
\hline & Salt $(\mathrm{g})$ & $<0.1$ & $<0.1$ & $<0.1$ & 0.1 \\
\hline \multirow{8}{*}{$\begin{array}{l}\text { BREAD } \\
(n=10)\end{array}$} & Weight (g) & 20.0 & 0.0 & 20.0 & 20.0 \\
\hline & Energy (kcal) & 54.3 & 0.7 & 53.2 & 56.8 \\
\hline & Carbohydrates (g) & 10.4 & 0.2 & 10.0 & 10.8 \\
\hline & Protein $(\mathrm{g})$ & 2.0 & 0.2 & 1.7 & 2.3 \\
\hline & Total fat (g) & 0.4 & $<0.1$ & 0.4 & 0.4 \\
\hline & SFA $(g)$ & 0.1 & $<0.1$ & 0.1 & 0.1 \\
\hline & Dietary Fibre (g) & 0.6 & 0.1 & 0.5 & 0.8 \\
\hline & Salt (g) & 0.3 & 0.1 & 0.3 & 0.4 \\
\hline
\end{tabular}

SD: standard deviation; MIN: minimum; MAX: maximum; SFA: saturated fatty acids.

The mean content of energy and nutrients compared to the reference values are presented in Table 3. The mean content of energy and carbohydrates did not reach the reference values, and the content of protein exceeded the reference value $(p<0.05)$. Mean salt and dietary fibre content exceeded the reference value, but did not differ significantly from the recommendations. Mean total fat and SFA content complied with the recommendations. 
Table 3. Weight and nutritional composition of total meal of school lunches analysed and compared to the reference value.

\begin{tabular}{|c|c|c|c|c|c|c|c|c|c|}
\hline & Per Dose & & $\begin{array}{l}\text { Reference } \\
\text { Values }\end{array}$ & Mean & SD & MIN & MAX & $\begin{array}{c}95 \% \text { CI } \\
\text { (Lower; Upper) }\end{array}$ & $p^{c}$ \\
\hline \multirow{8}{*}{$\begin{array}{l}\text { TOTAL MEAL } \\
\qquad(n=48)\end{array}$} & Weight & $\mathrm{g}$ & NA & 556.7 & 73.9 & 429.1 & 710.4 & NA & NA \\
\hline & Energy & $\begin{array}{c}\text { kcal } \\
\% \mathrm{DER}^{\mathrm{b}}\end{array}$ & $\begin{array}{c}492-574 \\
30-35\end{array}$ & $\begin{array}{c}454.4 \\
27.7\end{array}$ & $\begin{array}{c}95.3 \\
5.8\end{array}$ & $\begin{array}{c}282.1 \\
17.2\end{array}$ & $\begin{array}{c}690.0 \\
42.1\end{array}$ & $\begin{array}{c}399.4 ; 473.1 \\
24.4 ; 28.9\end{array}$ & $0.004 *$ \\
\hline & Carbohydrates & $\stackrel{\mathrm{g}}{\% \mathrm{E}}$ & $\begin{array}{l}68-92 \\
55-75\end{array}$ & $\begin{array}{l}54.7 \\
48.1 \\
\end{array}$ & $\begin{array}{l}9.0 \\
7.3 \\
\end{array}$ & $\begin{array}{l}36.6 \\
29.7 \\
\end{array}$ & $\begin{array}{l}71.3 \\
58.0 \\
\end{array}$ & $\begin{array}{l}48.6 ; 56.5 \\
39.5 ; 45.9\end{array}$ & $<0.001$ * \\
\hline & Protein & $\underset{\%}{\mathrm{~g}}$ & $\begin{array}{l}12-18 \\
10-15\end{array}$ & $\begin{array}{l}22.1 \\
19.5\end{array}$ & $\begin{array}{l}7.4 \\
6.0\end{array}$ & $\begin{array}{l}9.1 \\
7.4\end{array}$ & $\begin{array}{l}47.4 \\
38.5\end{array}$ & $\begin{array}{l}18.8 ; 23.6 \\
15.3 ; 19.2\end{array}$ & $<0.001$ * \\
\hline & Total fat & $\stackrel{\mathrm{g}}{\% \mathrm{E}}$ & $\begin{array}{c}8-16 \\
15-30 \\
\end{array}$ & $\begin{array}{l}14.5 \\
28.8 \\
\end{array}$ & $\begin{array}{c}7.0 \\
12.8 \\
\end{array}$ & $\begin{array}{l}5.0 \\
9.1 \\
\end{array}$ & $\begin{array}{l}35.4 \\
64.8 \\
\end{array}$ & $\begin{array}{l}11.9 ; 16.1 \\
21.7 ; 29.4\end{array}$ & 0.058 \\
\hline & $\begin{array}{l}\text { Saturated Fatty } \\
\text { Acids }\end{array}$ & $\underset{\%}{\mathrm{~g}}$ & $\begin{array}{l}5.5 \\
<10\end{array}$ & $\begin{array}{l}2.7 \\
5.4\end{array}$ & $\begin{array}{l}0.3 \\
0.6\end{array}$ & $\begin{array}{l}1.2 \\
2.2\end{array}$ & $\begin{array}{l}5.2 \\
9.6\end{array}$ & $\begin{array}{l}2.5 ; 3.3 \\
6.6 ; 6.0\end{array}$ & $<0.001$ \\
\hline & Dietary Fibre & $\mathrm{g}$ & 6.9 & 8.3 & 3.9 & 4.5 & 22.6 & $6.8 ; 9.1$ & 0.078 \\
\hline & Salt & $\mathrm{g}$ & $<1.5$ & 1.7 & 0.4 & 1.0 & 3.0 & $1.5 ; 1.8$ & 0.084 \\
\hline
\end{tabular}

SD: standard deviation; MIN: minimum; MAX: maximum; CI: confidence interval; DER: daily energy requirements; \% E: Energy standardized considering 30\% DER; NA: Not applicable. ${ }^{a}$ Total meal: soup + main course + bread + dessert; ${ }^{b}$ energy of total meal is presented in \% DER of six- to 10-year-old children (1640 kcal per day, according to the American guidelines). ${ }^{c}$ Since two-sided, one-sample $t$-tests were used, deviations of the estimated parameter are detected in either direction. Therefore, only significant differences that deviate from the recommendations are marked with an asterisk. ${ }^{*}$ Indicates significant differences that deviate from the recommendations.

\section{Discussion}

In agreement with previous studies [39-41], the content from the school lunches did not reach the reference values included in the guidelines for carbohydrates, but exceeded the reference values for protein. School lunches provided on average of $27.7 \%$ of the DER, which is slightly less than the $30 \%$ stated in the guidelines. The insufficient energy content is mainly due to the insufficient amount of carbohydrates provided.

The mean content of salt did not differ significantly from the reference values, unlike other national studies, where the mean content of salt exceeded recommendations [41,42]. This result might be due to the salt control policy already implemented in school canteens in Sintra [43]. Concerning salt content, the bread alongside the meal may contribute to an increase in the salt content of school lunches. The analytical analysis shows that the mean salt content in bread $(0.3 \pm 0.1 \mathrm{~g}$ in $20 \mathrm{~g}$ of bread $)$ is higher than the limit defined by the Portuguese legislation (1.4 g of salt per $100 \mathrm{~g}$ of bread) since 2009 [44]. Additionally, a collaboration protocol between the Directorate-General for Health, the National Institute of Health Doutor Ricardo Jorge, and the Associations of Bakery, Pastry and Similar Industries that goes beyond the current legislation established new goals for the reduction of salt in bread, with the ultimate goal of a maximum content of $1.0 \mathrm{~g}$ of salt per $100 \mathrm{~g}$ of bread. As intermediate targets, the following values were established: $1.3 \mathrm{~g}$ of salt per $100 \mathrm{~g}$ in $2018,1.2 \mathrm{~g}$ of salt per $100 \mathrm{~g}$ of bread in 2019 , and $1.1 \mathrm{~g}$ of salt per $100 \mathrm{~g}$ of bread in 2020 [45]. It is well-established in the literature the relationship between the excessive consumption of salt and non-communicable diseases [46]. Thus, the reduction of salt in bread is one of the key aspects to decrease daily salt consumption, since bread is generally manufactured by bakeries in which consumers have low power to choose [47]. Therefore, this result reinforces the importance of monitoring and evaluating food and nutritional policies. In addition, we must consider that the presence of tofu-a product with added salt-contributed to an increase the mean salt content, even though the mean salt content did not differ significantly from the recommendations. Tofu is only occasionally present on the school menu in Sintra—once in every 15 weeks—as recommended [48].

Although the content of dietary fibre shows disparities between lunches, the mean content did not differ significantly from the reference values. 
At the present study, the mean total fat and SFA complied with the recommendations. Regarding mean total fat, this result is concordant with another study [39], while the SFA result is not.

Actually, Portugal has been facing a diet transition, moving away from the traditional Mediterranean diet to a more Westernized diet [49]. Our results are aligned with national data about food availabilities [50], where the availability of the food group of meat, fish, and eggs was above the recommended consumption, and fruits and horticultural were below the recommended consumption. Furthermore, Portuguese National Food and Physical Activity Survey data [51] pointed out certain nutrients and foods in need of improvement. It was found that $83.2 \%$ of children have a daily intake of protein greater than $2 \mathrm{~g} / \mathrm{kg}$ weight. In children under 10 years old, it was described that the most consumed food group is meat, fish, and eggs. In addition, $16.3 \%$ of children ingest more than $100 \mathrm{~g} /$ day of red meat [37]. By contrast, cereals, fruits, and vegetables are the least consumed [51], with $72.0 \%$ of children not reaching WHO recommendations for fruit and vegetable consumption [36,51].

School meals have a great impact on children's health and wellbeing [6,7]. When compared with lunches prepared and/or consumed out of school, school lunches present better nutritional composition [52,53].

Although the average energy content of school lunches is below the recommendations, empirical knowledge by local canteen staff indicates the occurrence of plate waste. Thus, we cannot exclude the possibility that the canteen staff may serve portions that differ from recommendations, according to children's food preferences, to reduce plate waste. Moreover, the literature indicates that primary school children's snacks are mainly composed of foods and beverages high in fat, sugars, and salt, favouring a high energy contribution to children's daily energy needs [54,55]. This excessive dietary consumption before lunch could decrease children's hunger sensation for school lunches and contribute to plate waste.

Despite guidelines suggesting a contribution of $30 \%$ of DER at lunch [33], there is substantial plate waste in school canteens [12,56-58] and a high percentage of overweight school-aged children [51,59]. Thus, we reflected whether guidelines regarding the ideal contribution of each meal in DER should be reviewed for children.

Hence, it is well understood the implications of school lunches in the nutritional and overall health of the school community, as well as their impact in food systems. Thus, a perfect nutritionally designed menu is unworthy if there is substantial plate waste [60]. This becomes particularly critical when considering that different food types and healthier ingredients, specifically fruit and vegetables, are often the most wasted [13,60-63], influencing nutritional adequacy, mainly of micronutrients and dietary fibre. We suggest including children's lunch as pedagogical time in teachers' labour schedule. The supervision of teachers in school canteens is crucial, being capable of reinforce this setting as central in nutrition and health education, applying in practice knowledge, skills, and behaviours about healthy eating.

The authors are aware of the study limitations. The menu consists of 15 rotating weeks, and this analysis corresponds to one week out of the 15. In the future, it would be relevant to include a larger sample size and analytical analyses of other micronutrients, namely potassium, iron, iodine, zinc, calcium, and vitamin D to fully characterize the nutritional adequacy of school lunches $[39,64]$.

A major strength of this analysis is related to the accuracy of the materials and methods used to evaluate the nutritional composition of school lunches. Samples were analysed in an accredited laboratory; consequently, the results are not an assumption of the quantities present in the lunch technical sheets, nor the nutritional value based on nutritional composition tables present in books or reports. Moreover, the samples analysed corresponded to the actual portion served to children. Thus, the procedures defined for sampling, as well as the reliable methods for analysis of the school lunches, ensures more accuracy and a good reproducibility of the study. Furthermore, the assessment of school 
lunch nutritional adequacy was established considering international recommendations for the age group under study $[33,34]$.

The implementation of joint school food environment policies and food and nutrition education interventions are more efficient in enhancing children's dietary habits [11]. Sintra's municipality has recognized the role of such complementary policies and implements, and monitors a comprehensive and multicomponent school-based intervention: Sintra Grows Healthy [43]. Thus, ensuring coherent action between the integration of food literacy in the curriculum and the development of actions capable of modifying the school food environment is crucial to facilitate and support the adoption of healthy behaviours.

\section{Conclusions}

This study analysed the nutritional composition of school lunches in the primary schools of Sintra's municipality and indicated the need of improvement in the content of energy, carbohydrates, and protein when compared to current recommendations. Addressing school canteens is crucial, not only in a nutritional approach, but also as an opportunity to achieve healthier, sustainable, and accessible food systems aligned with the Sustainable Development Goals 2030. We highlight the importance of evaluating evidencebased practices and disseminating practice-based evidence regarding the adequacy of school lunches.

Author Contributions: Conceptualization, T.N. and R.J.F.; Data curation, T.N.; Formal analysis, T.N.; Investigation, T.N. and R.J.F.; Methodology, T.N.; Resources, R.J.F. and C.D.; Writing-original draft, V.D.d.S. and M.L.P.; Writing-review \& editing, T.N., R.J.F., C.D., and J.S. All authors have read and agreed to the published version of the manuscript.

Funding: This research received no external funding.

Institutional Review Board Statement: Not applicable.

Informed Consent Statement: Not applicable.

Data Availability Statement: The data presented in this study are available on request from the corresponding author.

Acknowledgments: The authors thank Ana Margarida Pereira for statistical advice.

Conflicts of Interest: Indústria e Comércio Alimentar provided support to cover the costs of the analyses of school lunches at an accredited and independent laboratory, Controlvet. Carlos Damas is an affiliate to Indústria e Comércio Alimentar, but played no role in the conceptualization, methodology, or data analyses of this study. All other authors report no conflicts of interest relevant to this article.

\section{Appendix A}

Table A1. Local menu of one week.

\begin{tabular}{|c|c|c|c|c|}
\hline Days of the Week & Soup & Main Course & Dessert & Bread \\
\hline Monday & Green bean soup & $\begin{array}{l}\text {-Stewed tofu and vegetable (tomato, } \\
\text { zucchini and mushrooms) and carrot rice } \\
\text {-Tomato and cucumber salad. }\end{array}$ & Watermelon & Sourdough bread \\
\hline Tuesday & French onion soup & $\begin{array}{l}\text {-Tuna with chickpea, potatoes, and carrot } \\
\text { salad } \\
\text {-Red cabbage and corn salad }\end{array}$ & Orange & Sourdough bread \\
\hline Wednesday & $\begin{array}{c}\text { "Caldo-verde" } \\
\text { Traditional Portuguese cabbage } \\
\text { soup }\end{array}$ & $\begin{array}{l}\text {-Portuguese duck rice } \\
\text {-Lettuce and beetroot salad }\end{array}$ & Apple & Sourdough bread \\
\hline Thursday & Turnip greens soup & $\begin{array}{l}\text {-Stewed squid with peas, carrots, and } \\
\text { potatoes }\end{array}$ & Jelly & Sourdough bread \\
\hline Friday & Lentil soup with white cabbage & $\begin{array}{l}\text {-Roasted and sliced pork and Fusilli } \\
\text { pasta } \\
\text {-Boiled broccoli and cauliflower }\end{array}$ & Banana & Sourdough bread \\
\hline
\end{tabular}




\section{Appendix B}

Table A2. Differed menu of one week.

\begin{tabular}{|c|c|c|c|c|}
\hline Days of the Week & Soup & Main Course & Dessert & Bread \\
\hline Monday & Pea cream & $\begin{array}{l}\text {-Tuna pie with rice base } \\
\text {-Tomato and sweet corn salad }\end{array}$ & Apple & Sourdough bread \\
\hline Tuesday & Leek cream & $\begin{array}{l}\text {-Turkey stroganoff with spaghetti } \\
\text {-Sautéed brussels sprouts and baby carrots }\end{array}$ & Orange & Sourdough bread \\
\hline Wednesday & $\begin{array}{l}\text { Bean soup with savoy } \\
\text { cabbage }\end{array}$ & $\begin{array}{l}\text {-Fish sticks in the oven with carrot rice } \\
\text {-Lettuce and cucumber salad }\end{array}$ & Banana & Sourdough bread \\
\hline Thursday & Zucchini soup & $\begin{array}{l}\text {-Roasted pork with fusilli pasta } \\
\text {-Sautéed turnip greens }\end{array}$ & Kiwifruit & Sourdough bread \\
\hline Friday & Watercress soup & $\begin{array}{l}\text {-Peasant salad (chickpea, potato, egg, and } \\
\text { carrot) } \\
\text {-Boiled broccoli and cauliflower }\end{array}$ & Pudding & Sourdough bread \\
\hline
\end{tabular}

\section{References}

1. Scaglioni, S.; De Cosmi, V.; Ciappolino, V.; Parazzini, F.; Brambilla, P.; Agostoni, C. Factors Influencing Children's Eating Behaviours. Nutrients 2018, 10, 706. [CrossRef] [PubMed]

2. Institute of Medicine. Nutrition Standards for Foods in Schools: Leading the Way Toward Healthier Youth; National Academies Press: Washington, DC, USA, 2007; ISBN 978-0-309-10383-1.

3. World Health Organization. Food and Nutrition Policy for Schools: A Tool for the Development of School Nutrition Programmes in the European Region; WHO Regional Office for Europe: Copenhagen, Denmark, 2006.

4. World Health Organization. Global Nutrition Policy Review 2016-2017: Country Progress in Creating Enabling Policy Environments for Promoting Healthy Diets and Nutrition; Cadman, H., Ed.; WHO: Geneve, Switzerland, 2018.

5. Nelson, M. School food cost-benefits: England. Public Health Nutr. 2013, 16, 1006-1011. [CrossRef]

6. Clark, M.A.; Fox, M.K. Nutritional quality of the diets of US public school children and the role of the school meal programs. J. Am. Diet. Assoc. 2009, 109, S44-S56. [CrossRef]

7. Turner, L.; Chaloupka, F.J. Slow Progress in Changing the School Food Environment: Nationally Representative Results from Public and Private Elementary Schools. J. Acad. Nutr. Diet. 2012, 112, 1380-1389. [CrossRef] [PubMed]

8. Benach, J.; Friel, S.; Houweling, T.; Labonte, R.; Muntaner, C.; Schrecker, T.; Simpson, S. A Concepetual Framework For Action On the Social Determinants Of Health; World Health Organization: Geneva, Switzerland, 2010; ISBN 9789241500852.

9. Willett, W.; Rockström, J.; Loken, B.; Springmann, M.; Lang, T.; Vermeulen, S.; Garnett, T.; Tilman, D.; DeClerck, F.; Wood, A.; et al. Food in the Anthropocene: The EAT-Lancet Commission on healthy diets from sustainable food systems. Lancet 2019, 393, 447-492. [CrossRef]

10. Balzaretti, C.M.; Ventura, V.; Ratti, S.; Ferrazzi, G.; Spallina, A.; Carruba, M.O.; Castrica, M. Improving the overall sustainability of the school meal chain: The role of portion sizes. Eat. Weight Disord. - Stud. Anorexia, Bulim. Obes. 2020, 25, 107-116. [CrossRef]

11. FAO. School Food and Nutrition Framework; FAO: Rome, Italy, 2019.

12. Derqui, B.; Fernandez, V. The opportunity of tracking food waste in school canteens: Guidelines for self-assessment. Waste Manag. 2017, 69, 431-444. [CrossRef] [PubMed]

13. García-Herrero, L.; De Menna, F.; Vittuari, M. Food waste at school. The environmental and cost impact of a canteen meal. Waste Manag. 2019, 100, 249-258. [CrossRef] [PubMed]

14. Storcksdieck Genannt Bonsmann, S.; Kardakis, T.; Wollgast, J.; Nelson, M.; Caldeira, S. Mapping of National School Food Policies (Print); Publications Office of the European Union: Luxembourg, 2014; ISBN 978-92-79-38401-1.

15. Baptista, M.I.M.; Lima, R.M.; Almeida, M.D.V. Educação Alimentar em Meio Escolar: Referencial para uma Oferta Alimentar Saudável; Direcção Geral de Inovação e do Desenvolvimento Curricular: Lisboa, Portugal, 2006.

16. Graça, P.; Gregório, M.J.; de Sousa, S.M.; Brás, S.; Penedo, T.; Carvalho, T.; Bandarra, N.M.; Lima, R.M.; Simão, A.P.; Goiana-daSilva, F.; et al. A new interministerial strategy for the promotion of healthy eating in Portugal: Implementation and initial results. Heal. Res. Policy Syst. 2018, 16, 102. [CrossRef]

17. Bento, A.; Cordeiro, T.; Frias, A.; Salvador, C.; Dias, D.; Amaro, L.F.; da Silva, R.; Gonçalves, C. Estratégia para a alimentação escolar em Portugal-Proposta. Acta Port. Nutr. 2018, 13, 8-13. [CrossRef]

18. Briggs, M.; Fleischhacker, S.; Mueller, C.G. Position of the American Dietetic Association, School Nutrition Association, and Society for Nutrition Education: Comprehensive School Nutrition Services. J. Nutr. Educ. Behav. 2010, 42, 360-371. [CrossRef]

19. Barnekow Rasmussen, V.; Rivett, D. The European Network of Health Promoting Schools-An alliance of health, education and democracy. Health Educ. 2000, 100, 61-67. [CrossRef] 
20. World Health Organization Global Strategy on Diet, Physical Activity and Health. Glob. Strateg. Creat. Sustain. Advant. across Borders 2004, 2002, 1-260. [CrossRef]

21. World Health Organization Regional Office for Europe; World Health Organization. European Food and Nutrition Action Plan 2015-2020; World Health Organization: Geneva, Switzerland, 2015; ISBN 9789289051231.

22. Commission Of The European Communities. White Paper on a Strategy for Europe on Nutrition, Overweight and Obesity Related Health Issues; Directorate-General Health and Consumer Protection: Brussels, Belgium, 2007; pp. 1-12.

23. FAO; WHO. Sustainable Healthy Diets; FAO: Rome, Italy; WHO: Geneva, Switzerland, 2019; ISBN 978-92-5-131875-1.

24. MUFPP. Milan Urban Food Policy Pact and Framework for Action; MUFPP: Milan, Italy, 2015.

25. Food and Agricutural Organization of the United Nations (FAO). Healthy Food Environment and School Food. Available online: http:/ / www.fao.org/school-food/areas-work/food-environment/en/ (accessed on 4 March 2021).

26. World Health Organization. Taking Action on Childhood Obesity Report; World Health Organization: Geneva, Switzerland, 2018.

27. Borowy, I. Sustainable health: The need for new developmental models. Bull. World Health Organ. 2014, 92, 699. [CrossRef] [PubMed]

28. European Commission. Food 2030: Future-Proofing our Food systems through Research and Innovation; European Commission: Brussels, Belgium, 2017.

29. United Nations. Transforming Our World: The 2030 Agenda for Sustainable Development; United Nations: New York, NY, USA, 2015.

30. Sintra's School Network. Available online: https:/ / cm-sintra.pt/atualidade/educacao/rede-escolar (accessed on 18 June 2020).

31. Lima, R.M. Orientações Sobre Ementas e Refeitórios Escolares; Ministério da Educação-Direção-Geral da Educação: Lisboa, Portugal, 2018.

32. European Parliament and of the Council Regulation (EU) 1169/2011 of the European Parliament and of the Council. Off. J. Eur. Union 2011, 18-59.

33. Institute of Medicine. School Meals; National Academies Press: Washington, DC, USA, 2010; Volume 12, ISBN 978-0-309-14436-0.

34. U.S. Department of Health and Human Services; U.S. Department of Agriculture. Dietary Guidelines for Americans 2015-2020; U.S. Department of Health and Human Services: Washington, DC, USA; U.S. Department of Agriculture: Washington, DC, USA, 2015; Volume 47.

35. Associação Portuguesa dos Nutricionistas. Capitações de Géneros Alimentícios Para Refeições em Meio Escolar: Fundamentos, Consensos e Reflexões; Associação Portuguesa dos Nutricionistas: Porto, Portugal, 2016.

36. Joint WHO/FAO Expert Consultation. Diet, Nutrition and the Prevention of Chronic Diseases; WHO: Geneve, Switzerland, 2003; Volume 916.

37. The Caroline Walker Trust and National Heart Forum. Eating Well at School: Nutritional and Practical Guidelines; The Caroline Walker Trust and National Heart Forum: St Austell, UK, 2005.

38. World Health Organization. Guideline: Sodium Intake for Adults and Children; World Health Organization: Geneva, Switzerland, 2012.

39. Osowski, C.P.; Lindroos, A.K.; Barbieri, H.E.; Becker, W. The contribution of school meals to energy and nutrient intake of Swedish children in relation to dietary guidelines. Food Nutr. Res. 2015, 59, 27563. [CrossRef] [PubMed]

40. Juniusdottir, R.; Hörnell, A.; Gunnarsdottir, I.; Lagstrom, H.; Waling, M.; Olsson, C.; Talvia, S.; Olafsdottir, A.S. Composition of School Meals in Sweden, Finland, and Iceland: Official Guidelines and Comparison With Practice and Availability. J. Sch. Health 2018, 88, 744-753. [CrossRef] [PubMed]

41. Fontes, T.; Bento, A.C.; Matias, F.; Mota, C.; Nascimento, A.C.; Santiago, S.; Santos, M. O valor nutricional de refeições escolares. In Boletim Epidemiológico Observações; Insitituto Nacional de Saúde Doutor Ricardo Jorge: Lisboa, Portugal, 2015; Volume 4, pp. 25-27.

42. Paiva, I.; Pinto, C.; Queirós, L.; Meister, M.C.; Saraiva, M.; Bruno, P.; Antunes, D.; Afonso, M. Baixo valor calórico e elevado teor de sal: Nas refeições servidas em cantinas escolares. Acta Med. Port. 2011, 24, 215-222. [PubMed]

43. Ferreira, R.J.; Nogueira, T.; Dias da Silva, V.; Liñan Pinto, M.; Sousa, J.; Pereira, A.M.; Nogueira, P.J.; Borrego, R.; Raposo, A.; Martins, J.; et al. A school-based intervention for a better future: Study protocol of Sintra Grows Healthy. BMC Public Health 2020, 20, 1615. [CrossRef] [PubMed]

44. Assembleia da República Lei 75/2009. Diário República 2009, 155, 5225-5226.

45. Ministérios das Finanças; Administração Interna Educação, Saúde, Economia, Agricultura; F. e D.R. e M. Diário da República, $2^{a}$ série- $N^{o}$ 249-29 dezembro 2017; Despacho no 11418/2017; 2017; pp. 29595-29597.

46. Malta, D.; Petersen, K.S.; Johnson, C.; Trieu, K.; Rae, S.; Jefferson, K.; Santos, J.A.; Wong, M.M.Y.; Raj, T.S.; Webster, J.; et al. High sodium intake increases blood pressure and risk of kidney disease. From the Science of Salt: A regularly updated systematic review of salt and health outcomes (August 2016 to March 2017). J. Clin. Hypertens. 2018, 20, 1654-1665. [CrossRef] [PubMed]

47. Food Safety Authority of Ireland. Salt and Health: Review of the Scientific Evidence and Recommendations for Public Policy in Ireland (Revision 1); Food Safety Authority of Ireland: Dublin, Ireland, 2016.

48. Lobato, L.; da Silva, S.G.; Cramês, M.; Santos, C.T.; Graça, P. Planeamento de Refeições Vegetarianas para Crianças em Restauração Coletiva: Princípios Base; DGS: Lisboa, Portugal, 2016.

49. Chen, Q.; Marques-Vidal, P. Trends in food availability in Portugal in 1966-2003: Comparison with other Mediterranean countries. Eur. J. Nutr. 2007, 46, 418-427. [CrossRef] [PubMed] 
50. INE Instituto Nacional de Estatística. Balança Alimentar Portuguesa 2012-2016; INE Instituto Nacional de Estatística: Lisboa, Portugal, 2012.

51. Lopes, C.; Torres, D.; Oliveira, A.; Severo, M.; Alarcão, V.; Guiomar, S.; Mota, J.; Teixeira, P.; Rodrigues, S.; Lobato, L.; et al. Inquério Alimentar Nacional e de Atividade Física, IAN-AF 2015-2016: Relatório de resultados; Universidade do Porto: Porto, Portugal, 2015.

52. Evans, C.E.L.; Mandl, V.; Christian, M.S.; Cade, J.E. Impact of school lunch type on nutritional quality of English children's diets. Public Health Nutr. 2016, 19, 36-45. [CrossRef] [PubMed]

53. Kinderknecht, K.; Harris, C.; Jones-Smith, J. Association of the Healthy, Hunger-Free Kids Act with Dietary Quality among Children in the US National School Lunch Program. JAMA - J. Am. Med. Assoc. 2020, 324, 359-368. [CrossRef]

54. Piernas, C.; Popkin, B.M. Trends In Snacking Among U.S. Children. Health Aff. 2010, 29, 398-404. [CrossRef]

55. Beets, M.W.; Tilley, F.; Kyryliuk, R.; Weaver, R.G.; Moore, J.B.; Turner-McGrievy, G. Children Select Unhealthy Choices when Given a Choice among Snack Offerings. J. Acad. Nutr. Diet. 2014, 114, 1440-1446. [CrossRef] [PubMed]

56. Cohen, J.F.; Richardson, S.; Austin, S.B.; Economos, C.D.; Rimm, E.B. School Lunch Waste Among Middle School Students. Am. J. Prev. Med. 2013, 44, 114-121. [CrossRef]

57. Eriksson, M.; Persson Osowski, C.; Malefors, C.; Björkman, J.; Eriksson, E. Quantification of food waste in public catering services - A case study from a Swedish municipality. Waste Manag. 2017, 61, 415-422. [CrossRef] [PubMed]

58. Byker, C.J.; Farris, A.R.; Marcenelle, M.; Davis, G.C.; Serrano, E.L. Food Waste in a School Nutrition Program After Implementation of New Lunch Program Guidelines. J. Nutr. Educ. Behav. 2014, 46, 406-411. [CrossRef] [PubMed]

59. Instituto Nacional de Saúde Dr. Ricardo Jorge. Childhood Obesity Surveillance Initiative COSI Portugal_2019: Preliminary Data; Instituto Nacional de Saúde Dr. Ricardo Jorge: Lisboa, Portugal, 2019.

60. Derqui, B.; Fernandez, V.; Fayos, T. Towards more sustainable food systems. Addressing food waste at school canteens. Appetite 2018, 129, 1-11. [CrossRef]

61. Betz, A.; Buchli, J.; Göbel, C.; Müller, C. Food waste in the Swiss food service industry-Magnitude and potential for reduction. Waste Manag. 2015, 35, 218-226. [CrossRef] [PubMed]

62. Marlette, M.A.; Templeton, S.B.; Panemangalore, M. Food type, food preparation, and competitive food purchases impact school lunch plate waste by sixth-grade students. J. Am. Diet. Assoc. 2005, 105, 1779-1782. [CrossRef] [PubMed]

63. Smith, S.L.; Cunningham-Sabo, L. Food choice, plate waste and nutrient intake of elementary- and middle-school students participating in the US National School Lunch Program. Public Health Nutr. 2014, 17, 1255-1263. [CrossRef] [PubMed]

64. Hess, J.; Slavin, J. Snacking for a Cause: Nutritional Insufficiencies and Excesses of U.S. Children, a Critical Review of Food Consumption Patterns and Macronutrient and Micronutrient Intake of U.S. Children. Nutrients 2014, 6, 4750-4759. [CrossRef] [PubMed] 